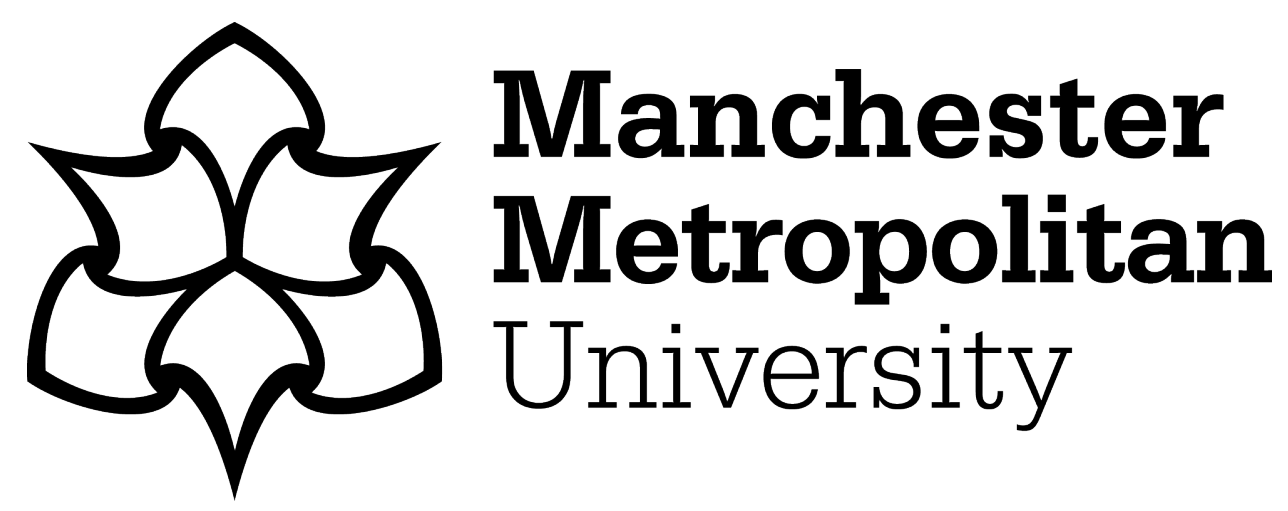

Di Ciolla, N (2017) Discursive strategies of genre hybridisation in Gianrico Carofiglio's essays and novels: towards a consensual language of truth and justice. Forum Italicum: a journal of Italian studies, 51 (1). pp. 45-60. ISSN 0014-5858

Downloaded from: https://e-space.mmu.ac.uk/326/

Version: Accepted Version

Publisher: SAGE Publications

DOI: https://doi.org/10.1177/0014585816682484

Please cite the published version 


\title{
Discursive strategies of genre hybridisation in Gianrico Carofiglio's essays and novels: towards a consensual language of truth and justice
}

\begin{abstract}
Justice is a recurrent theme in the writings of Gianrico Carofiglio, in particular the novels and the essays. In these works, great attention is paid to how justice is delivered through the Italian legal processes, how it is conceived by those who are entrusted with its administration, and how it is perceived by citizens. Through the analysis of a sample corpus, comprising two essays and two of the novels of the Guido Guerrieri cycle, this contribution examines a range of strategies used by the author to configure his vision of justice. A preliminary overview appears to suggest a pronounced difference between novels and essays with regard to the author's own stance towards justice. Whilst the novels echo the nationally shared distrust for what is considered to be a system that is dysfunctional, and deserves to be critiqued and contested, the essays encourage readers to embrace a consensual, positive view of the principles of justice. The main contention in this contribution is that the apparently resigned portrayal of a flawed justice system found in the novels contains the same desire and points to the same social and ethical perspective as the essays. Through a reflection on the topoi that emerge in the texts, and through the analysis of their key themes and the observation of some of their linguistic features (including lexical frequency and distribution), this contribution brings to the fore the ideological, as well as stylistic coherence that exists between the two sets of texts.
\end{abstract}

\section{Keywords}

Carofiglio, interdiscursivity, Italian crime fiction, crime fiction and the law.

Gianrico Carofiglio (b. 1961) - formerly an anti-mafia prosecutor in Bari, and former member of the Italian Senate - is one of Italy's most prolific and best-selling writers, as well as one of the forerunners of the fortunate breed of practitioners of law and justice that from the early 2000s has taken the world of Italian crime fiction by storm. As the first Italian author to have transposed the tense and dynamic plots and atmospheres of the courtroom, hitherto the prerogative of North American authors and settings, to an unmistakably Italian context, he is generally acknowledged as the pioneer of the Italian courtroom drama (Past, 2012: 108). Although his popularity is mostly linked to the cycle of legal thrillers featuring defence lawyer Guido Guerrieri, Carofiglio is also author of short stories, non-genre novels, a legal handbook, and works of non-fiction. ${ }^{1}$ 
His concern for the topoi of justice and truth, the way they are represented, mediated, and become part of cultural patterns, emerges as a clear leitmotif in the entire corpus.

This essay analyses a selected cross-genre sample of the works, focussing on the range of discursive strategies deployed by the author to configure and convey his vision of justice, to illustrate how justice is embodied in the Italian legal processes, how it is manipulated, perceived and conceived, both by those directly involved in its administration, and by the wider community. The analysis aims to establish the extent to which genre requirements affect, or limit, the ways in which the pursuit of what is giusto and vero - words that appear frequently and in a range of morphological derivates in the texts chosen - can be represented and conveyed, resulting in an effective 'segregation of topics' between novels and essays.. To this end, Carofiglio's early fictional work featuring defence lawyer Guido Guerrieri, published from the early 2000s, has been considered alongside his two main non-fictional texts to date, one on cross-examination in the criminal courts and the other on the ethics of language, published later, between the mid- and the late 2000s. A preliminary overview of this sample corpus reveals that the stance assumed with regard to justice is largely a function of the genre of the text, resulting in a representation of the pursuit of justice, and a construction of its significance, which are not the same in the novels as they are in the essays. This is, one can argue, a predictable consequence of the nature of the two text types: they respond to different imperatives - in the novels, it is the requirement to tell a captivating story set in a context that the reader finds plausible; in the essays, it is the wish to configure a world with a high aspirational charge for the reader. Further, novels and essays understandably deploy different narrative strategies; they are conceivably directed at two different types of implied reader, and they possibly end up reaching a different constituency of real readers. I want to investigate the extent of this difference, to see whether there is an objective demarcation in Carofiglio's writing, a deliberate partitioning of competences between fiction and non-fiction, or conversely this is a surface impression likely to change on closer analysis. Whether the conventions of the genre chosen impose the type of message that the author considers reasonable to convey, resulting in a clear distinction between fictional and non-fictional output. Or, as I intend to demonstrate, an internal coherence can be found, a core message that runs through the entire oeuvre, articulated differently, 
recontextualised, carried through different discursive and narrative strategies to fit the medium. Thus conceived, the novels and the essays become part of an interconnected system for narrating society, and the role of justice and truth in society, the links of what in Critical Discourse Analysis is called a 'genre chain' (Fairclough 2003). The focus hence shifts from the analysis of the works' individual generic specificities to their consideration as distinctive but interrelated parts of the same discourse.

\section{L'arte del dubbio, La manomissione delle parole, and the role of language as an instrument of truth and justice}

In the essays L'arte del dubbio (2007) and La manomissione delle parole (2010), the author presents an ambitious and shareable vision of what justice should be and how it should be administered, arguing rationally and authoritatively in its defence. He reconstructs the founding principles of justice to demonstrate their universality, and invites readers to pursue truth and justice through the collective exercise of logos - intended by Carofiglio as the wise, honest and transformative use of reasoning and language. The following extracts, taken from the incipits of L'arte and La manomissione respectively, articulate this view:

\footnotetext{
La comunicazione non è semplicemente uno strumento per rappresentare oggetti da essa separati o in essa contenuti; essa invece condiziona costitutivamente la struttura stessa dei fatti e delle conoscenze. (Carofiglio 2007:14, emphasis added)

Mi ha sempre affascinato l'idea che le parole ... nascondano in sé un potere diverso e superiore rispetto a quello di comunicare, trasmettere messaggi, raccontare storie ... che abbiano il potere di produrre trasformazioni, che possano essere, letteralmente, lo strumento per cambiare il mondo.

Spesso, tuttavia, le nostre parole hanno perso significato perché le abbiamo consumate con usi impropri, eccessivi o anche solo inconsapevoli ...

La ragione di questo libro - a un tempo politica, letteraria ed etica - consiste nell'esigenza di trovare dei modi per dare senso alle parole: e, dunque, per cercare di dare senso alle cose, ai rapporti fra le persone, alla politica intesa come categoria nobile dell'agire collettivo.(Carofiglio, 2010: 15-16, emphasis added)
}

L'arte del dubbio is a reworking of the cross-examination manual Il controesame: dalle prassi operative al modello teorico, a text originally aimed at criminal law practitioners and public prosecutors, and published by Carofiglio in 1997 with Giuffré, a publishing house specialising in legal manuals. The amended version, published 10 years later with a more philosophical title, edited out the most specific legal technicalities and was refashioned into a handbook that offered 'spunti di 
riflessione sul rapporto tra linguaggio, persuasione e verità' (2007: 12). It was no longer directed at specialists in the legal disciplines, but addressed instead the general public interested in learning how witnesses are cross-examined in trials, and wishing to understand the methodologies for constructing a good argument through a series of 'storie' (12) drawn from transcripts of trials. Thus, although the text continues to illustrate the skills of a good cross-examiner, whose oratorical expertise is functional to the achievement of a positive outcome for the client, its premise is that a solid argument must lead to persuasive and acceptable conclusions, and to the truth. The definition of truth, suggests the author, is a point that can be demonstrated beyond reasonable doubt, and compared to which any alternative propositions are statistically impossible. The authorial position throughout the text is entirely pragmatic and factual, sustained by solid and sensible principles that are presented as free from ideological bias, and for this reason can be widely agreed upon.

A similar reflection on the power of logos and on the dangers of an improper use of words inspires La manomissione delle parole (2010). Whilst arguing in general against the widespread practice of using language carelessly and irresponsibly, whether by chance or by design, and warning against the perils of doing so, the text sets out to restore to their original dignity five nouns in particular: vergogna, giustizia, ribellione, bellezza and scelta, which in the Italian context have become conceptually impoverished. Carofiglio employs the instruments of philology and cultural history to demonstrate the performative power of linguistic practice, and to prove that persisting in a fraudulent, or simply incorrect, use of language results in a distorted image of reality, which in the long run is (mis)taken for reality itself. Citing copiously from the Western tradition - from the classics (Plato, Thucydides, Aristotle, Sallust, but also Dante) to 20th century culture (George Orwell, Primo Levi, Nadine Gordimer, up to Bob Marley and the Italian press) -, La manomissione historicises and contextualises the habit of 'tampering with words', and presents examples that, for their unexpected congruence with the Italian context, should occasionally make the Italian reader feel uncomfortable. The extended citation from Orwell's Nineteen Eighty-Four (1949), particularly its description of the systematic purging of meaning carried out by the authorities in charge of codifying Newspeak, becomes more than a literary reference to a dystopian but fictional reality when it is juxtaposed to 
examples of comparable linguistic manipulations occurring in Italy. Carofiglio refers for instance to the semantic twisting of the term lodo, an instrument included in the Italian civil code, technically designed to settle disagreements between two litigants amicably and out of court. ${ }^{2}$ Despite its established tradition dating back to the Middle Ages, and its unambiguous codification in the current civil code, the term lodo seems to have surreptitiously undergone a semantic revolution. From the early 2000s, it has been used in the Italian institutional and media lexicon to define something that is the opposite of what the original meaning intended, namely legislation introduced in the national system not to resolve a controversy, but solely and patently to safeguard vested, one-sided interests. ${ }^{3}$ The repeated misuse of a term that designates a juridical instrument of conciliation to refer to what is effectively an abuse of political and/or economic power results in a 'grave violazione del principio di uguaglianza dei cittadini' (79). This is not dissimilar to what occurs in Orwell's fictional province of Airstrip One in Nineteen Eighty-Four (1949), as a consequence of the imposition of Newspeak to replace English. Carofiglio quotes from Orwell's account of the innovations brought in through Newspeak, in which words such as '[o]nore, giustizia, morale, internazionalismo, democrazia, scienza e religione avevano semplicemente cessato del tutto di esistere', to be replaced by fewer terms that arbitrarily summed up the concepts. The remainder of the quotation, which reports that ' $[t] u t t e$ le parole che si raggruppavano intorno ai concetti di libertà e di eguaglianza, ad esempio, erano contenute nella semplice parola psicoreato' (La manomissione, 2010:88, emphasis in the original) echoes ominously Carofiglio's concern for the safety of the principle of equality in Italy, expressed a few pages earlier. ${ }^{4}$

If it is possible to manipulate language, to steal meaning from words - Carofiglio calls the manomissori 'ladri di parole' (46) - and even arbitrarily relocate words to the opposite end of the semantic spectrum (aligning uguaglianza with psicoreato, as in the cited example from Orwell). If violations of rights and general abuses of power can become accepted praxis. If the words used to name such violations and identify them for what they are have been removed from the lexicon, or their meaning has been altered beyond recognition, this could only have happened with the silent consent of the rest of the population. The general indifference with which abuses of power are received in Italy, 
the acquiescence, or resignation, of Italian citizens in the face of attacks on the institutions and universal rights, hubristically carried out by those in power, have been widely reported. ${ }^{5}$ In La manomissione delle parole, Carofiglio borrows the words used by Antonio Gramsci in the 1917 invective Indifferenti to express the dangers of apathy and indifference, which, as Gramsci states, are powerful forces in history, and the cause of evil in society. The indifferent multitude, argues Gramsci, abdicates its own will, and by doing so 'lascia fare ... lascia promulgare leggi che poi solo la rivolta farà abrogare, lascia salire al potere gli uomini che poi solo un ammutinamento potrà rovesciare. ${ }^{6}$ Whilst the indifferent multitude looks away, Gramsci continues, 'poche mani, non sorvegliate da nessun controllo, tessono la tela della vita collettiva, e la massa ignora, perché non se ne preoccupa'. This deeply rooted, collective habit of looking the other way, of growing so accustomed to malpractice that it becomes accepted as practice, is exposed forcefully and cogently in La manomissione delle parole, and put to shame not only through examples of the damages it causes to society - as illustrated by the citations from Orwell, from Gramsci, or from prominent contemporaries such as Gustavo Zagrebelsky and Luciano Canfora, but also through a constructive reminder of what a civilised society should look like and is indeed capable of being like, and how responsible citizenship is part of our genetic makeup. This is the sense of the quotation from Pericles' funeral oration to the Athenians (83), which in its extended version commends the citizens' respect for the laws of the land and the unanimous indignation towards transgressors, and invites us to consider public service as a privilege. It is also the sense of the reference to the other meaning of the word manomissione, which in ancient Rome indicated the practice of freeing individuals from slavery: manumissio marks the start of a new life, a rebirth. Not an intervention that causes damage, but a regenerative one, that enables a better present and future.

\section{The Guido Guerrieri novels: what lies behind the stories of everyday (in)justice}

Compared to the firm belief in truth and to the ambitious vision of a just society so lucidly advocated in the essays, the kind of justice that is foregrounded in the novels of the Guerrieri cycle conventionally aligned with the courtroom drama subtype of the crime genre (Di Ciolla, 2009: 707) appears remarkably tamed, domesticated, often reduced and impoverished. The expectations of the 
individual - narrator and characters- are shown to be minimal, as are the efforts to serve justice made by those who are officially entrusted with its safeguard and application. As suggested earlier, a plausible explanation that would account for these apparently substantial differences exists: in the fictional work, the need to preserve a measure of realism, or verisimilitude, forces the author to downplay his conceptualisation of justice as a universal, metaphysical value that directs and corrects human actions. As it is customary for crime fiction authors, Carofiglio must take into account the notorious limitations and anomalies of the Italian justice system, some of which are due to its being co-opted to serve the interests of lobbies instead of those of the entire community of citizens. None of this is an issue in the essays, where, on the contrary, the authorial stance is allowed to be at the same time theoretical and technical, wholly principled, distanced from the observable praxis and therefore not liable to the humiliation of a reality check. I would like to suggest, however, that encoded in the novels, behind the apparent disenchantment and the resigned acceptance of a status quo that is however acknowledged as far from ideal, lies the same appetite and aspiration for the clear and linear justice that is represented in the earlier essays. To demonstrate this, I will examine the two sets of texts from the thematic and linguistic point of view. I will borrow from the tools of critical discourse analysis to identify the possible interrelation between essays and novels, I will explore the notion of genre hybridisation to explain how the two sets of texts can be situated along a continuum, and will borrow aspects of corpus linguistics to reflect on the significance of lexical choices, distribution, concordances and collocates.

Carofiglio's debut as a novelist happened while he was working as a Public Prosecutor sostituto procuratore - in Bari. Because of the kind of stories and situational dynamics he created in his works, he was initially dubbed by many of his reviewers in the press il John Grisham all 'italiana, or the inventor of the legal thriller all'italiana. ${ }^{7}$ These definitions, with their systematic recourse to foreign points of reference, be they authors or genres, clearly indicate the absence of known or discernible Italian terms of comparison or antecedents for Carofiglio's writings. The recurrence of the lexeme all'italiana defines the author and the novels as participants in a process involving both 
contamination and assimilation. If the tag, typically employed in a pejorative sense, warns of a possible spaghettizzazione of the genre, it also suggests that, by assimilating North American modes of narrating courtroom practices, Carofiglio will by default throw some light on the proverbially muddy Italian ones.

The protagonist of the Guerrieri series is the eponymous character and autodiegetic narrator, who works as a defence lawyer in the Southern Italian city of Bari. Although the novels do not invite a reading as transcripts of criminal trials, they can be taken as plotted commentaries on particular aspects of the criminal justice system in Italy. As it is customary with fiction that presents plausible situations and adheres to the principles of realism of place, readers are tempted to assume that the references made in the texts are to real practices, if not to real cases - an assumption reinforced by the author's well publicised (although now formally concluded) association with the judiciary. A consequence of this referential uptake of the novels' topoi is that Carofiglio's stories featuring avvocato Guido Guerrieri tend to be read as a critical reflection on the pernicious nature of the justice system in Italy, which the bonhomie of the autodiegetic narrator's voice only manages to emphasise. Carofiglio's fictional world is inhabited by judges who are slovenly and deferential to (often illegitimate, often Mafia) power; by lawyers who only take on cases where victory is assured, or where the professional disappointment of a defeat can be offset by the handsome fees gained. It is a world where money and good connections guarantee impunity, and where the rights of vulnerable individuals are not reliably safeguarded by the institutions. The inspiration may well come from an American original model, but Carofiglio cannot easily be accused of epigonality. His depiction of what happens in the courts is uncomfortably 'close to home', depriving the Italian reader of the privilege of a view from a safe distance: the situations, the places, the character types, the social dynamics are all very recognisably Italian - southern Italian, but not to the exclusion (or exoneration) of everyone else in the rest of the country. If a spaghettizzazione has taken place, it has not produced a timid and tame derivation. By a similar token however, I would argue that the Guerrieri stories also compel a reflection on the acceptability of such a status quo and, more importantly, the envisioning of desirable and attainable alternatives. I will focus mainly on the first two novels of the series - Testimone inconsapevole (2002) and Ad occhi chiusi (2003) - because they mark Carofiglio's debut as a writer, deal with two issues (racism and gender violence) that remain, ten years on, at the top of the Italian political agenda, as well as foremost in the public attention, and at 
the same time provide an accurate and still current overview of contemporary Italian society. Reference to the third novel in the series, Ragionevoli dubbi (2006) will be made in relation to a significant element that links it to La manomissione delle parole and that supports the hypothesis of the robust conceptual and ideological connection that runs across the entire oeuvre.

In Testimone inconsapevole Guerrieri represents an African immigrant, Abdou Thiam, who is the main suspect in the case of the abduction and murder of a nine year old local boy. The body of evidence stacked up against his client appears to be large and mounting, and although it is constituted mostly by eyewitness statements, and is questionable because entirely circumstantial, it is considered by the investigators as conclusive. The urge to be publically seen to have solved the case is such that, four days into the investigation, 'carabinieri e pubblico ministero avevano trionfalmente raccontato in conferenza stampa che il caso era risolto' (44). On the dubious strength of this evidence, Thiam is charged on three counts, which Guerrieri lists with professional accuracy, or pedantry, referencing them to the relevant articles of the Criminal Code as: 'rapimento di minore (art $605 \mathrm{cp}$ ), delitto di minore (art $575 \mathrm{cp}$ ) e occultamento di cadavere (art $412 \mathrm{cp}$ )' (43). With no clear sense of what the murder weapon was and no evidence of sexual violence detected on the body of the victim, the authorities publically declare the suspect a paedophile murderer and place him under arrest.

The evidence, although objectively weak in itself and repeatedly qualified by the narrator as such, seems to draw strength from the context, from the pervasive and ill-concealed racism of the local community that the authorities do not seem overly inclined to challenge and that - at the beginning of the narrative at least- Guerrieri also noncommittally shares. For this reason, although as the narrative advances he becomes increasingly persuaded of Thiam's innocence, he remains pessimistic about the chances of a favourable outcome of the trial. He advises his client to opt for the safer option of a plea bargain instead. The process of 'giudizio abbreviato' - Guerrieri explains in another wholly technical aside which temporarily halts the flow of the narrative to provide legal data (63-4) - entails a preliminary admission of guilt; it means certainty of a guilty verdict and a likely, if comparatively less harsh, sentence to twenty years in prison. The 'rinvio a giudizio', by contrast, would result in a long trial and in a sentence to life imprisonment, in the case of a guilty verdict. Although, Guerrieri admits, statistics show that in a full trial there is a $10 \%$ chance of acquittal - an opportunity not available with 
the plea bargaining route (90) - he is convinced that this particular instance would sit squarely within the majority of cases, and a guilty verdict would be the most likely outcome. '[A]ndare in dibattimento significa solo un inutile massacro' (77) he concludes: 'inutile' because avoidable with a prompt admission of guilt; a massacre because Thiam will be treated as the ideal scapegoat, the reification of all the community's worst fears and deepest hatred. His case will be made an exemplar of how a white western community can protect itself and excise the dangerous 'foreign body'.

In the novel, Thiam refuses the offer of shortcuts and asks to go for full trial so that he can clear his name. Guerrieri prepares for what he senses is going to be an arduous task. In narrating the days and weeks leading up to the trial, the narrator provides a series of snapshots of his professional environment. His description of the world of judges, prosecutors and lawyers, and in general of the system for administering justice in Italy, matches exactly what is in the public imagination - the narrator confirms to the readers what they already know, either through personal experience or because absorbed through the shared reservoir of common knowledge. The text provides plenty of evidence of limited professional deontology, suggesting that professional competencies and subject knowledge are routinely put to mercenary use. Lawyers defend criminals because they are paid to do so, regardless of the fact that they know that they are dealing with 'ladri, truffatori, rapinatori, bancarottieri. Anche qualche spacciatore' (Ad occhi chiusi, 13), who, thanks to their services, escape punishment. ${ }^{8}$ The text also provides evidence of a world dominated by generalised indifference and predominance of self-interest over the interest of justice. Lawyers, prosecutors and judges play tactical games for purely private gains, procrastinating or, conversely, rushing through proceedings to limit personal involvement and effort to the minimum. In $A d$ occhi chiusi the narrator explains that plea bargaining is a favoured instrument with prosecutors and judges because '[s]i fa tutto molto in fretta, l'udienza finisce a metà mattina e ognuno può andarsene in santa pace a casa, o dove gli pare'. He adds immediately afterwards that lawyers too like plea bargaining, for the reason that '[s]i fa tutto molto in fretta e ognuno può andarsene in santa pace in studio, o dove gli pare' (23). The near-verbatim repetition effectively bundles the entire body of justice professionals together, emphasising the large distance that separates the work they actually do from the work society imagines they should be doing. 
As well as a nonchalant attitude towards the defence of justice, the text reports also numerous instances of blatant disregard of laws and norms. Guido Guerrieri routinely accepts payment in cash to avoid paying tax, a practice in use amongst many of his colleagues. And when he cashes in his fees, he does so knowing that they come from 'denaro acquisito attraverso reato' (66) and are generally constituted by 'soldi sporchi' (67).

Overall, the world described by the narrator, with a large amount of self-deprecating irony, is one in which the rights of individuals are not safeguarded in the name of a universal principle, but depend on social standing, networks of influence, and ultimately money.

A similarly disconcerting picture of the justice system emerges from the second novel, Ad occhi chiusi, published the following year, in 2003. In this instance too Guerrieri accepts a case that is described as doomed from the start, for reasons that are different but comparable to those outlined in the earlier novel. Reasons that have little to do with collective and objective notions of innocence or guilt, but exclusively with the identity and position in society of the parties involved in the dispute.If, in the debut novel, representing a Senegalese immigrant meant taking on racial prejudice and an entrenched society bent on protecting itself from external pressures - the narrator says that he felt like the protagonist of 'una Capanna dello zio Tom ambientata a Bari' (Testimone, 157) - in Ad occhi chiusi Guerrieri is standing against the power and might of the Bari bene, its connections and its means. By agreeing to represent a young woman in a lawsuit against her violent ex-partner (who is the member of a prominent local dynasty - himself a professor of medicine, and the son of the president of one of the criminal sections of the Court of Appeal), Guerrieri is challenging the omnipotence and impunity of the now proverbial Casta. ${ }^{9}$ He is making the unreasonable claim that the principle according to which all citizens are equal in the eyes of the law be upheld in practice, even if this means questioning the actions of the local oligarchy, and sanctioning them. The narrator says that his involvement in this case will have unavoidable professional repercussions for him - it will destroy his career (37) - and pragmatically regrets not having the wisdom of those colleagues who had been approached before him, and had declined the assignment.

With the typical understated irony with which Guerrieri describes his personal vicissitudes, his weaknesses and his professional life, the reader is told that accepting this client was not so much an act 
of valour from a man who believes in justice, who wants to defend legality and punish crime; and neither was it an act of hubris, of presumption deriving from excessive confidence in his ability as a lawyer. It was just a case of foolhardiness, of not being able to say no when it would have been prudent to do so. And yet, despite the cynicism of his reflections, despite the disheartening descriptions of people and situations in the Italian courts of law, the text, like the previous one, does suggest that change is possible, as well as desirable, and points to very factual steps that can be taken to set this change in motion.

If we consider the narratives' dénouement, in Testimone inconsapevole, the Senegalese suspect is acquitted; in Ad occhi chiusi the omnipotent Professor Scianatico, the femicide (taken in the broad semantic value of someone who exercises violence on women), is found guilty and given a custodial sentence. Testimone inconsapevole concludes with a long and lucid closing statement, in which Guerrieri urges the eight judges to distinguish between truth and semblance of truth, between what is vero and what is verosimile - not just a philological matter, but an ethical one too-, and return a verdict which is just because tenable beyond reasonable doubt. As the trial is conducted in a Corte d'Assise, where six of the judges are lay members, representatives of the community of citizens, that closing statement is symbolically addressed to the community of citizens the panel metonymically stands for. The narrative's ending, which sees the return of a non-guilty verdict, does seem to suggest that the intended message has been received. The final pages of Testimone inconsapevole contain many other strong and positive statements about the value of the justice system and the trust it deserves even when we do not immediately understand or agree with its conclusions. One example of these is encrypted in a reflection that the narrator makes thinking of his first ever trial, one that he lost - inexplicably, he thought at the time. That defeat had convinced him that the judge's deliberation against the defence had been arbitrary and unjust, and this had made him lose faith in justice. 'Non mi passò neanche in mente la spiegazione più ovvia della faccenda: il mio cliente era colpevole e il giudice aveva fatto bene a condannarlo. Questa fu una brillante intuizione che ebbi solo molto tempo dopo' (301-2, my emphasis). There can be method in this justice, Guerrieri is telling the reader, except that it may not be immediately obvious to an observer.

Unlike Testimone inconsapevole, the story narrated in Ad occhi chiusi has a tragic ending: the defendant, accused of stalking and of physical and psychological abuse - 'maltrattamenti e violenza 
privata aggravata' (31) - is not held in custody during the trial because the judge does not consider him dangerous, despite all the evidence suggesting otherwise. His freedom enables him to hound his accuser, Guerrieri's client, and beat her to death in her own home. From the textual and the diegetic points of view, this outcome closes a loop opened with the incipit, which listed the victim's failed attempts to put an end to the persecution: on three separate occasions she had pressed charges, and only on the third had the authorities intervened and started investigating - a pattern which echoes real practices, reported daily in the news, in Italy and elsewhere. The outcome chosen by Carofiglio prevents the novel from providing a comprehensively neat and reassuring resolution. Guerrieri's client becomes a victim of femicide because the system has failed to protect her - but protected her persecutor instead, because of his 'vantaggio di posizione', an unearned advantage that everyone accepted unquestioningly. And it takes a murder to break the impunity of an untouchable like Scianatico - the killer - because for anything less, as he boasts earlier in the novel, 'nessuno avrebbe mai avuto il coraggio di toccarlo' (33).

Justice appears to be done in this story, albeit at great cost and with a course which is not entirely natural, automatic or procedurally correct. Firstly, the reader is told, the police must deliberately omit some details from their reports in order not to give the killer's powerful connections the chance to find legal loopholes and get him released on technicalities. Secondly, as is often the case in Italy, it is the media that takes on a crucial watchdog role, ensuring that justice takes its proper course: they keep the levels of public interest in the case and the pressure on the courts high, which safeguards the fairness of the trial and guarantees that the sentence passed is commensurate to the crime committed. Under such sustained public attention, the original sentence is confirmed on appeal, because 'così sotto l'attenzione dei media, nessuno voleva rischiare l'accusa di avere favorito il figlio del presidente Scianatico' (248). These two elements do lead the reader to conclude that, unless appropriate correctives are applied, in the Italian justice system 'just' outcomes are not automatically guaranteed. But they also show that correctives do exist, they can be effectively applied, and positive outcomes can be achieved. Carofiglio's chosen narrative strategy enable the texts to function according to what Eco calls 'a flexible system of signification' (Eco, 1979: 3): the text creates spaces for the reader to make a series of interpretative choices, and opportunities to balance the significance of the various elements presented, enabling the reader to become a participant in the construction of the meaning of the narrative. In 
making sense of the events in the Guerrieri stories, the reader has the option: to accept the status quo the familiar and consolidated situation of widespread corruption and reckless individualism, where the institutions are disempowered and, in their endemic inability to offer reparation to victims, they protect the criminals; or accept the challenge, and embrace the ambition for a different culture of justice.

\section{Interdiscursive hybridity and the construction of a shared view of justice}

To demonstrate the hypothesis that Carofiglio's work - whatever its genre - is fundamentally inspired by the same system of values, evidence must be found that these values are encoded in the novels as they are in the essays, that they are similarly embedded in the structures of authorship and reception, and in the stories narrated. To identify and examine more closely the links between the essays and the novels, some of the tools developed in linguistics can be useful, particularly Norman Fairclough's reflections on the functions, meaning and interplay of texts. While Fairclough's intention is to analyse the function and meaning of a text in a way that enables linguists to bring 'a social perspective into the heart and fine detail of the text' (2003: 28), I propose to use his observations in the reverse direction, searching for granular level linguistic details that can corroborate my hypothesis of the shared social and ethical perspective between the two sets of texts, formulated on the basis of the analysis of narrative elements. Drawing from the studies of M.A.K. Halliday (1978), Fairclough classifies the functions performed by texts and the meaning of texts along three major categories. The textual 'functions', which he calls ideational, interpersonal and textual, indicate the ability of a text to represent aspects of the world; create connections between the various participants in the textual world, in terms of attitudes, desires and values; and finally maintain internal coherence, and coherence with the situational context, the world outside the text (26-27). The textual meaning results from the interplay of three major orientations: representation, action and identification. Representation refers to how the text describes the world, and is an aspect linked to discourse. Action is what the text 'does': what the narratee is told, or promised, warned against, and is an aspect linked to genre. Identification is the undertaking, commitment, or judgement expressed from within the text, and is an aspect linked to style (27). 
In comparing the two corpora - fictional and non-fictional - I have considered some of the linguistic features, searching in particular for recurring lexicon, which could confirm the presence of a shared standpoint beyond the simple fact of the common authorship. Referring to Fairclough's analytic categories of representation, action, and identification, I have then analysed the texts to identify the type of world that they describe, the type of relationship that they establish between narrator and narratee, and the type of message they carry, to corroborate my initial hypothesis regarding their congruence. A brief analysis of the lexicon used in the novels and in the essays reveals the recurrence of certain key words. The relative frequency of giustizia and giusto, for example, is comparable in both corpora: the two words are fairly evenly dispersed in the novels, with some specific evidence of clustering appearing in chapter 7 of La manomissione delle parole - a part entirely dedicated to a discussion of the theme of justice. ${ }^{10}$ Excluding the occurrence of the words giusto when it is used as an interjection signifying agreement, and giustizia when it is part of locative lexemes such as corte di giustizia or palazzo di giustizia, the novels contain a significant number of references to the notions of just and justice as values to be pursued and safeguarded, if often against the odds, including examples of explicit definitions of what justice should be. ${ }^{11}$ A similar observation can be made about the occurrence and dispersion of the words vero and verità, whose use in the novels is as value-laden as it is in the essays. These sets of key words are used in both novels and essays in highly performative expressions (Nuyts, 2001: 39) that clearly foreground the author/narrator's position with regard to the values they encode, and his commitment towards their realisation (Frawley et al., 2006: 15). However, the clearest evidence of the conceptual connection between fiction and essays is the anticipation of the genesis of La manomissione, made in the novel Ragionevoli dubbi, published four years earlier. Nearly half way through the story of Ragionevoli dubbi, Guerrieri finds himself in his usual bookshop where his attention is drawn to a small volume with the title La manomissione delle parole (subtitle: appunti per un seminario sulla scrittura creativa), no author's name printed on the cover. The protagonist reads 'alcune frasi' (Ragionevoli dubbi 128), four paragraphs in total, set apart from the main diegesis through the use of italics, he is captivated by the topic and takes the book away. The entire episode from Ragionevoli dubbi, which is four pages long, is reported verbatim in the incipit of La manomissione (9-13). It is prefaced by an apology for the self-citation and followed by the explanation that, whilst at the time of Ragionevoli 
dubbi, La manomissione delle parole was an imaginary work, pressure from readers and the author's own interest in the vicissitudes of words meant that it is now a reality. The incorporation of a part of the (yet to be written) essay into one of the novels, and later of part of a novel into the essay, is the most factual demonstration of the ideal bond - the chain- that binds together Carofiglio's work, and of the similar orientation that characterises it, intended as the commitment of the text to its addressees. And from the lack of authorial attribution of the little booklet found by Guerrieri in Ragionevoli dubbi it is reasonable to infer that even back then Carofiglio wanted to claim authorship of La manomissione for himself, avoiding even a temporary, fictional ascription to an imagined alias.

In L'arte del dubbio and La manomissione delle parole Carofiglio appears to 'fly high' because of the genre of the works - they are treatises, they are by their very nature invested with values, they are oriented towards a consensual narrative, and declare their intention from the outset. Conversely, the novels, which choose to adhere to more stringent mimetic rules, present a much more nuanced discourse, enriched by a graded set of modalities, which blur the stark opposition between right and wrong, truth and error, but equally, as a close reading demonstrates, lead the reader to a new consensus and agreement about what justice could be. In the novels, narrator and narratee set off from a common ground - understood as 'the mutual knowledge, beliefs and assumptions shared by the speaker and addressees' (Clark et al., 1983: 246-247). This common ground is constructed from perceptual and linguistic evidence, and on community membership: both narrator and narratee refer to a comparable experience of contextual reality, which they have heard and/or described in comparable ways; they have come to a particular understanding of what this reality is by virtue of being members of a group that interacts in it. Through a carefully constructed discourse, and through the exercise of the technique of argumentation, which Carofiglio describes in L'arte del dubbio as 'lo strumento per pervenire alla verità' (205), the common ground to which the novels appeal becomes more than the mere one occupied by all that is despicable and objectionable in the Italian context today. Instead it expands to include the (more difficult to reach) portion occupied by hope and constructive stance, by a commitment to change. What is foregrounded in the Guerrieri novels is a message that goes beyond the common belief that the justice system is irredeemably flawed-reiterated through the caricatured representation of judges and 
lawyers, or of the idiosyncratic practices in place; it encodes instead the desire and feasibility of an alternative despite all that. Therefore, the message of aspiration to a true and just society, which is core in the essays, is simply recontextualised in the novels, reformulated to make it appropriate to the different genre. It is shaped in order to ensure that the stories remain within the range of plausibility for the reader; it is covert, but not at all lost. This is achieved through a fluid use of rhetorical strategies throughout the whole corpus, which results in the genres of fiction and non-fiction frequently and easily transitioning into each other, creating a genre chain where each text engages in a dynamic relation with the preceding or the following one, in a system of genre and textual relations that Fairclough calls interdiscursive hybridity (35). The tone changes that are present in the novels open up a space for didascalic, philosophical reflections even amidst the most realistic and disparaging scenes of everyday injustice, abuses, and generalised indifference. By blurring the genre boundaries, these transitional elements, liberally dispersed in the texts, become powerful and effective devices for making the language of responsible and responsive citizenship visible, accessible and usable to a wider range of audiences, and the discourse on justice and truth one in which all feel enabled to participate.

\section{NOTES}

\footnotetext{
${ }^{1}$ The non-crime fiction works include the collections of stories Non esiste saggezza (2010) and Cocaina (2013); the graphic novel Cacciatori nelle tenebre (illustrated by Francesco Carofiglio, 2007); the novels Il passato è una terra straniera (2004), Né qui né altrove (2008), Il silenzio dell'onda (2011), Il bordo vertiginoso delle cose (2013), and La casa nel bosco (co-authored with Francesco Carofiglio, 2014). Works aligned to the crime genre but without Guerrieri as protagonist are the dialogue Il paradosso del poliziotto (2009), and the novel Una mutevole verità (2014) which the author describes in the blurb as 'la cosa più vicina a un poliziesco classico che abbia mai scritto'. The Guerrieri novels so far are Testimone inconsapevole (2002), Ad occhi chiusi (2003), Ragionevoli dubbi (2006), Le perfezioni provvisorie (2010), and La regola dell'equilibrio (2014). The most recent addition to the non-fictional work is Con parole precise. Breviario di scrittura civile (2015). ${ }^{2}$ In Italian civil law, the term lodo (abbreviation of lodo arbitrale) indicates a compromise solution that composes a controversy between two opposing parties out of court, through the mediation of an impartial third party. To prove the conceptual simplicity and etymological clarity of the term, In La manomissione Carofiglio does not refer the reader to a juridical text for reference, but to the entry 'lodo' in the Devoto-Oli dictionary of Italian language (173).

${ }^{3}$ Most of the recent examples of lodo were subsequently repealed by the Corte Costituzionale. For a discussion of the decision of the Constitutional Court see for example Martinico G. (2010) The Berlusconi Judgment: A Brief Case Note on the Decision of the Italian Constitutional Court (Note 262/2009). European Public Law 16: 231-238.

${ }^{4}$ The references to Orwell's Nineteen Eighty-Four present in La manomissione come from the Italian edition translated by Gabriele Baldini, published by Mondadori in 1973. This quotation can be found on p. 336 of that edition.

${ }^{5}$ The indifference of the Italians to routine abuses of power has been analyzed in many books and is denounced daily by journalists and commentators. See, amongst others Ainis M (2004) Le libertà negate: come gli italiani stanno perdendo i loro diritti. Milan: Rizzoli; De Monticelli R (2010) La questione morale Milan: Raffaello
} 
Cortina Editore; Rizzo S and Stella GA (2011) Licenziare i padreterni. L'Italia tradita dalla Casta. Milan: Rizzoli.

6 'Indifferenti' was published in the first and only issue of La città futura, the journal of the Federazione giovanile piemontese of the Partito Socialista Italiano, written entirely by Gramsci and published in February 1917. The full issue, including the full text of 'Indifferenti' is also available online at http://www.antoniogramsci.com/cittafutura.htm\#indifferenti . The quotations come from the online version (last accessed 1 March 2015).

${ }^{7}$ See, amongst others, Foschini P (2004) La vita è un poker di presunti innocenti. Corriere della sera, 29 August.

${ }^{8}$ Asked by his partner Margherita if he believes that Thiam is innocent, Guerrieri answers: 'Non lo so. In un certo senso non è un problema mio. Ci tocca difenderli meglio che possiamo, siano innocenti o colpevoli. La verità, se esiste, devono trovarla i giudici. Noi dobbiamo difendere gli imputati' (181).

${ }^{9}$ The use of the word casta to refer to the Italian élite and its extensive unearned privileges has become popular after the Corriere della Sera journalists Sergio Rizzo and Gian Antonio Stella published the essay La Casta. Cosi i politici italiani sono diventati intoccabili (2007).

${ }^{10}$ To calculate the relative frequency (which in statistics indicates the ratio of the frequency of an event to the total count of events) I have considered the occurrence of a given word over a total word count set at 10,000 words. I would like to thank my colleague Jessica Frye for her insights into lexical distribution, concordances and collocates in the corpora in question.

${ }^{10}$ An interesting example is in Testimone inconsapevole, where the prosecutor, after declaring that his duty is to seek justice, provides a definition of 'true justice': ‘[L]a giustizia è tale quando, accertate con rigore le responsabilità, con altrettanto rigore commina pene commiserate alla gravità dei fatti’ (165)

\section{WORKS CITED}

Ainis M (2004) Le libertà negate : come gli italiani stanno perdendo i loro diritti. Milano: Rizzoli. Carofiglio G (2002) Testimone inconsapevole. Palermo: Sellerio.

Carofiglio G (2003) Ad occhi chiusi. Palermo: Sellerio.

Carofiglio G (2006) Ragionevoli dubbi. Palermo: Sellerio.

Carofiglio G (2007) L' arte del dubbio. Palermo: Sellerio.

Carofiglio G (2010) La manomissione delle parole. Milano: Rizzoli.

Clark HH, Schreuder R and Buttrick S (1983) Common Ground and the Understanding of Demonstrative Reference. Journal of Verbal Learning and Verbal Behaviour 22: 245-258.

De Monticelli R (2010) La questione morale Milan: Raffaello Cortina Editore.

Eco U (1979) The Role of the Reader: Explorations in the Semiotics of Texts. Bloomington ; London: Indiana University Press.

Fairclough N (2003) Analysing Discourse:Textual Analysis for Social Research. London: Routledge.

Frawley W, Eschenroeder E, Mills S, et al. (2006) The expression of modality.

Gramsci A, D’Orsi A and Fondazione Istituto piemontese Antonio Gramsci (2004) La nostra città futura: scritti torinesi (1911-1922). Roma: Carocci.

Halliday MAK (1978) Language as Social Semiotic: the Social Interpretation of Language and Meaning. London: Edward Arnold.

Martinico G (2010) The Berlusconi Judgment: A Brief Case Note on the Decision of the Italian Constitutional Court (Note 262/2009). European Public Law 16: 231-238.

Nuyts J. (2001) Epistemic modality, language, and conceptualization : a cognitive-pragmatic perspective, Amsterdam ; [Great Britain]: J. Benjamins.

Orwell G (1949) Nineteen Eighty-Four. A novel. London: Secker \& Warburg.

Past E (2012) Methods of Murder: Beccarian Introspection and Lombrosian Vivisection in Italian Crime Fiction. Toronto: University of Toronto Press.

Rizzo S and Stella GA. (2007) La casta : così i politici italiani sono diventati intoccabili, Milano: Rizzoli.

Rizzo S and Stella GA (2011) Licenziare i padreterni. L'Italia tradita dalla Casta. Milano: Rizzoli. 
